\title{
'Abdu'l-Bahá's Response to the Doctrine of the Unity of Existence
}

\section{Keven Brown}

\begin{abstract}
The specific doctrine of the "unity of existence" (wahdat al-wujúd) in Islam originated with the teachings of the Sufi master Ibn 'Arabí, and it soon became widely accepted by other Sufis. Among the philosophers it had a notable influence on the ideas of Mullá Șadrá whose al-Asfár al-Arba'a (The Four Journeys), remains at the center of traditional philosophical studies in Iran. The doctrine holds that existence (wujúd) belongs only to God, while the essences of all other things are uncreated manifestations or self-determinations of God's hidden being. 'Abdu'l-Bahá states that although the evidence for this viewpoint is complete and perfect from a certain perspective, relative to the station of the mystic, a higher stage exists wherein the mystic beholds only God while recognizing the essences of things as created and distinct from His Essence.
\end{abstract}

\section{Résumé}

La doctrine particulière de "l'unité de l'existence » (waḥdat al-wujúd) dans l'Islam, prit naissance dans les enseignements du maître soufi Ibn 'Arabi, et elle se répandit rapidement parmi les autres soufis. Chez les philosophes, elle influença grandement la pensée de Mullá Șadrá dont l'œuvre, al-Asfár alArba'a (Les quatre voyages), demeure toujours au premier plan des études philosophiques traditionnelles en Iran. Cette doctrine soutient que l'existence (wujúd) n'appartient qu'à Dieu tandis que toutes les autres choses, dans leur essence, sont des manifestations incréées de l'être caché de Dieu. 'Abdu'l-Bahá affirme que, bien que sous un certain angle, la preuve de ce point de vue soit parfaite, par rapport au rang du mystique, il existe un degré plus élevé où le mystique ne voit que Dieu tout en considérant les choses, dans leur essence, comme étant créées et distinctes de l'essence divine.

\section{Resumen}

La doctrina específica en el Islam de "la unidad de la existencia" (waḥdat alwujúd) originó con las enseñanzas del maestro sufí Ibn 'Arabí, y al poco tiempo llegó a ser ampliamente aceptada por otros sufies. Entre los filósofos la doctrina tuvo notable influencia en las ideas de Mullá Sadrá, cuyo al-Asfár al-Arba'a (Los Cuatro Viajes) sigue al centro de los estudios filosóficos tradicionales en el Irán. La doctrina mantiene que la existencia (wujúd) pertenece solamente a

(C) Association for Bahá'í Studies 2001. 
Dios, mientras que las esencias de todas las otras cosas son manifestaciones increadas o autodeterminaciones del ser escondido de Dios. 'Abdu'l-Bahá dice que, aunque la prueba de este punto de vista sea completa y perfecta desde cierta perspectiva con respecto al nivel espiritual del místico, existe una etapa más alta en la cual el místico percibe solamente a Dios, reconociendo a la vez las esencias de las cosas como creadas y distintas de Su Esencia.

\section{Background}

In my article, "'Abdu'l-Bahá's Response to Darwinism," in Evolution and Bahá'i Belief, I introduced a Platonic interpretation of the term "species" as used in the writings and talks of "Abdu'l-Bahá. To differentiate this Platonic understanding of "species" from the modern definition, I chose to refer to the former by the expression "species essence." Species essences, which are equivalent to Platonic Forms, were described as the timeless immaterial causes, or laws, by which the manifold beings of the physical universe are realized. ${ }^{1}$ In studying the Sufi doctrine of wahdat al-wujúd ("unity of existence" or "oneness of being"), the nature of the relationship of these essences to God is important. In other words, what is the ontological status of these realities? Are they created and substantially different from the Essence of God, or are they uncreated and in some sense indistinct from God's Essence? If they are indistinct, then the existence of God and the existence of the creature are also, in some sense, indistinct. It is argued in this paper that 'Abdu'l-Bahá favors the first position, that of the createdness and distinctness of the essences and potentialities of things from the Essence of God. (By "creation" in this article is meant the religious concept of a Creator Who freely creates something new and novel from what is outside Himself, as a painter creates a painting.)

The conflict between these two positions, which can rather generally be labeled existential monism and existential dualism, has a long history in Islam. I emphasize "rather generally" because the two positions are very complex. Both camps agree, for example, that "that by which all things exist is one," namely God. This is a form of monism. In this paper, however, I am using the term "monism" to refer to the concept of God being immanent in creation through manifestation, and reserve the term "dualism" for the concept that God is ever transcendent from creation and only has a relation to it through emanation. There have been philosophers in both camps, while most Sufis followed some variant of the monist position and most theologians and jurists upheld the

\footnotetext{
1. In the Tablet on the Universe (Lawh-i-Aflákíyyih), 'Abdu'l-Bahá claims a specific role for God's names and attributes in creating the world: "Praise be to God, Who has ever caused the effects of His names and attributes to penetrate the degrees of existence.... He has ordained these names and attributes to be the first principle of giving existence in the world of creation and the source of the different grades of realities in the degrees of existence" (Makátíb 1:13). The species essences are, in some sense, ontological structures of the divine names and attributes. Note: all passages from 'Abdu'l-Bahá and Bahá'u'lláh quoted from Persian sources are provisional translations.
} 
dualist position. Although the famous Sufi master Ibn 'Arabí (1165-1240) did not coin the technical term wahdat al-wujúd himself, he is recognized as the founder of this idea, and it is clearly implicit in his teachings. ${ }^{2}$ Existence (wujúd), Ibn 'Arabí explains, belongs exclusively to God, while it is on loan to His creatures, similar to the way that light belongs exclusively to the sun, but it is borrowed by those who dwell on earth. Creation is the manifestation of wujúd, which is God. For example, in his al-Futúhát al-Makkíyya, he says: "It is impossible for the things other than God to come out of the grasp of the Real [haqq], for He brings them into existence, or rather, He is their existence. . . . Concerning the existents in all their differentiations, we maintain that they are the manifestation of God. ..." (qtd. in Chittick, Sufi Path of Knowledge 94-95).

Julian Baldick gives a concise interpretation of wahdat al-wujúd as he understands Ibn 'Arabí:

Ibn 'Arabi declared that there is only one ultimate Reality in the whole of existence. This is certainly monistic, but not the same thing as pure monism, which maintains that there is only one entity. So we should call his theory by its own title: "the unity of existence" (wahdat al-wujud). The one ultimate Reality is sometimes seen as "the Truth" (haqq ... ), the Essence of all things; sometimes as "creation" (khalq . . ), the manifestation of the Essence. The Truth is the One, the Lord. Creation represents the many, the slaves. So paradoxes arise: the Truth simultaneously is creation and is not. In helping God to reveal himself, and in knowing him, the mystic in fact creates him. The One appears in images in mirrors, as colours in substances, and as food permeating bodies. Thus the various objects in the universe are God, but he is not limited to being identical with any one of them taken in isolation. Nor is he identical with the universe taken as the sum total of its constituent parts: the doctrine of Ibn 'Arabi is not pantheism (the belief that all is God and God is all)... (83)

Given that Baldick's interpretation may have merit, a word of warning is appropriate here in regard to studying Ibn 'Arabí. William Chittick has pointed out that Ibn 'Arabí's perspectives constantly change because he is describing what became known to him experientially in different waystations of the mystical quest. Hence, "it is relatively easy to have Ibn al-"Arabí say what one wants him to say... . But he has many other views as well. If we make no attempt to take those views into account, we will misrepresent him" (Chittick, Self-Disclosure ix). In light of this, it is necessary to distinguish between the actual views of Ibn 'Arabí (which future scholarship will continue to elaborate) and the views of Ibn 'Arabí's followers and interpreters. The meaning of the term 'ayn (pl. a'yán), for instance, changed from "individual entity" in Ibn "Arabí's writings to "archetype" (that is, Platonic Form) in the writings of

2. Ibn 'Arabí's disciple, Sadr al-Dín Qúnawí, who helped systematize Ibn 'Arabí's teachings and correlate them to philosophy, used the expression wahdat al-wujúd in his writings, and it was soon adopted as a technical term in reference to Ibn 'Arabí's doctrine. 
Mullá Șadrá and his successors, a change which has substantial implications for differences in their theories of knowledge.

Among the Sufis, Shaykh Ahmad Sirhindí (1564-1624) is noted for seeking to "correct" the theory of wahdat al-wujúd, which he perceived as pure monism, by proposing the counter doctrine of wahdat al-shuhúd ("unity of vision" or "unity of witnessing"). He believed that Ibn "Arabí and his followers, in focusing on the idea that existence belongs exclusively to God, were denying the real existence of other entities. He explained it was like seeing only the sun and denying the existence of the stars. Sirhindí considered Ibn 'Arabí and his followers to be blinded by their ecstasy, and therefore excused them. But, he says, there is a higher stage, "unity of vision" (wahdat al-shuhúd), which means recognizing God's unity and seeing it reflected in all things while knowing that other things do in fact exist (Baldick 121). He held that creation is not a manifestation or determination of God, as the strict followers of wahdat alwujúd maintained, but "a determination of non-being with a reflection of the Divine wujúd on it" (Ansari 150).

The Muslim philosopher Avicenna (980-1037), likewise, had pointed out a dualism fundamentally distinguishing God's existence from the existence of His creatures. He held that existence and essence have a different but equal reality in contingent beings, making them composite: "That whose existence is necessary through another, be it an eternal being, cannot have an uncompounded nature [basit al-haqíqa], because that which it possesses through itself [that is, essence] is different from that which it possesses through another [that is, existence]. It obtains its being [al-huwíyya] in real existence from both factors together" (qtd. in Sadrá 1:66). But God's existence, on the other hand, is truly uncompounded, because His existence is identical to His Essence.

The philosopher Mullá Șadrá (ca. 1571-1640), who was strongly influenced by the ideas of Ibn 'Arabí, blurred or removed Avicenna's distinction between the existence of God and the existence of creation, and his writings tend toward existential monism. For example, in his Kitáb al-Mashácir, Șadrá says: "That existence which is the reality of every existent is God" (al-wujúd al-ladhí huwa haqíqa kull-i mawjúd innahu huwa'lláh) (qtd. in Ahsá'í 93). Sadrá has God's existence only differing in intensity, not kind, from the other existents, so there is one reality of existence underlying both God and things (1:433). This existence has overflowed from God through the exuberance of His act of contemplating himself (His first self-manifestation), and it then becomes differentiated into all the modes of existence by God's attributes, which to Sadrá are no other than the aspects of God's own being (Rahman, Philosophy 80, 86-87, 145). Sadrá also taught the identity of the perceiver and the perceived in the intellect, so that when God contemplates the possibilities of things in His mind, He is really contemplating aspects or properties of His own being. 
For Mullá Sadrá, God's overflowing existence is that by which things subsist foundationally, their ultimate matter, and the creatures themselves are each unique manifestations or self-disclosures of God's hidden being. There is thus no real separation between God and His creatures at the level of essences nor with respect to the existence by which they become actualized.

\section{Shaykh Aḥmad's Response to Mullá Șadrá}

Shaykh Aḥmad Ahssá'í (1753-1825) was one of the important precursors of the views of 'Abdu'l-Bahá on this subject. Shaykh Ahmad was fond of quoting the following verse often: "God was alone and nothing was with Him. He now is as He has always been." He intends by this verse to establish the doctrine that the existence of God is utterly separate from contingent existence. Accordingly, Shaykh Ahmad says that what Mullá Șadrá calls "existence" (wujúd) is really something created by God through His action, and it is the same as primary matter (mádda or hayúlá). Shaykh Ahmad applies many names to this first effect of God's action, such as the Recipient (al-maf'úl), the Light of God (núr Alláh), the Breath of the Merciful (nafas al-rahmán), the First Water (al-má' alawwal), the Muhammadan Reality (al-haqíqa al-muhammadíyya), and existence (al-wujúd), but with the explicit understanding that this existence is created (makhlúq) and proceeds (fá'id) from God's action. God remains "the real existence" (al-wujúd al-haqq) through Whom all things exist, though not by His Essence but by His action. Shaykh Ahmad denies that God is the First Cause in the sense that other philosophers mean, which is as a direct cause of things: "If I mean by the First Cause the Essence of the Creator, this is false, because the Essence of the Creator is not the direct cause of any thing. . . Only His fashioning [san"] is the cause of things; nor is it true that anything emanates from His Essence . . unless we mean by it His action. . . We follow the teachings of the holy Imams, who say the first direct cause is the action of God" (140).

In all of this Shaykh Aḥmad opposes Mullá Sadrá's doctrine of the unity of God and creation with respect to existence. He says: "He [Șadrá] is adamant that creation is the same in kind as the Creator. . . We are adamant that creation is not the same in kind as the Creator and there is no reflection of Him. Its Fashioner only created it by His creative action, not from something. . . The 'thing' is only from His Will [mashíyya], and it is called a 'thing' [al-shay'] because it is willed [masha'an]" (198). In other words the term "thing" cannot be applied to what God creates "things" from, because things are subsequent to being willed and are themselves expressions of the Will; therefore, He is said to create by His Will, not from something (lá min shay'). Lá min shay' is usually translated "from nothing," but this is misleading because it gives the impression that God creates things out of absolute nothingness, which is not a position held by Shaykh Ahmad. Instead, things are created from a "non-thing" which is 
foundationally its own cause: matter, or the first undifferentiated and active aspect of God's creative Will.

A clear statement of the position Shaykh Ahmad is opposed to is expressed in the words of one of Mullá Șadrá's followers, Mullá Muḥsin Fayḍ, in his Kalimát al-Maknúnah (Hidden Words), where he says:

God would not have brought it [the creature] into being unless it had a fixed archetype in the Divine Knowledge. . . . [for] the recipient is the same as the agent, and the uncreated archetype [al-'ayn] is the same as God, so His action and receptivity are His two hands. He is the agent by one of His hands and the recipient by the other. The Essence [of God] is one, and the multiple are impressions [in Him]. Thus it is true that He has created nothing except Himself, and what He has created are His manifestations. (Qtd. in Ahsá'í 16)

Whereas Mullá Șadrá placed God's existence as the common ground of all things, Shaykh Ahmad placed matter and form together as the common ground of creation. This matter (mádda), being coextensive with God's action, is itself active $(f a ́ c i l)$, but it requires its complement, form (șúra), which is receptive (infi'ál), to be realized. And these two-matter and form-to Shaykh Ahmad, denote the same thing as existence (wujúd) and essence (máhíyya) within the contingent realm. For example: "In regard to every existential reality . . . we have established that existence is matter, and it is not realized in the real world except by a formative element (muqawwim), which configures it, and this is the essence, or form. We mean by this existence that which is created, not necessary or absolute [that is, God's existence]. Whatever they [Șadrá and his followers] say has a determination is really derived from this existence [which is matter]" (Aḥsá'í 25).

Shaykh Ahmad's "matter" is conceptually preceded in creation by God's Will, which is identical to God's action, or act of creating, and to all of God's actional attributes. In short, what God's Essence is is different from what it does. Shaykh Ahmad holds that all of God's attributes connected to creation, such as His providence and His knowledge of His creatures, are "attributes of His action" (228), not attributes of His Essence. For example, when we say "God is knowing," "knowing" expresses the state of God in the act of knowing. Although this action is "with" God, it is not in the actor but is distinguishable from the actor and essentially posterior to the actor from whom it originates. Shaykh Ahmad says:

He [Mullá Sadrá] intended to establish how God knows things, but we can only ask this if we mean the created knowledge which is the universal and particular Tablets of [created things]. . . . It is incorrect to say that He knows things in His eternal state, because nothing of them is in Him, nor is it permissible to say that He is ignorant of things in their states. . . When He brings things into being, then He knows them. . . And His [essential] states do not change, so that He should be lacking something or 
acquiring [wájid] something. Nay, He never ceases in His eternal state from acquiring them in their times and places [in His created knowledge]. . . "God was and nothing was with Him. He now is as He has ever been." . . . As for his [Șadrá's] doctrine that every perceptual form is one in existence with the perceiver . . it is false. (203, 205, 187)

Shaykh Ahmad, consequently, locates the species essences, or fixed archetypes of things, in God's created knowledge, not in God's Essence: "The fixed archetypes exist only in the first stage [of creation, that is, that of the Will], not in the Essence of God" (204). They are "with" God as His action, but not "in" God. The Sufis of Ibn 'Arabi's school and Mullá Șadrá, on the contrary, because of their belief in the unity of perceiver and perceived in the intellect, had claimed that the archetypes are posited (or "fixed") in God's Essence. In sum, Shaykh Ahmad's main point of difference with Mullá Sadrá was over the nature of contingent existence. Whereas Șadrá saw it as something


complete rupture separates the two, and in place of Sadrá's "existence" he put "matter" created by and coextensive with God's action.

\section{'Abdu'l-Bahá's Response to the Doctrine of the Unity of Existence}

What 'Abdu'l-Bahá accepted from the "philosophers of the East" was a fundamentally Platonic worldview and a Neoplatonic metaphysics. What all of these philosophers agreed upon was that God created the world by His act of thinking it (First Intellect) or uttering it (God's Word) or breathing it (Breath of the Merciful). They agreed that the universe was not self-existent but required a Creator to order it and to give it existence from outside. But they disagreed upon the nature of the "ideas" in God's mind and their relation to God, and they also disagreed on how God created the world (that is, how He derived multiplicity from oneness) and what exactly was meant by "creation." No one disputed that all material and temporal beings are created and preceded by their own nonexistence, but what about the archetypes or essences in God's knowledge?

Mullá Șadrá and his followers taught, in accordance with their doctrine of the identity of the perceiver and the perceived, that the essences of things are uncreated and identical to God's Essence in the state of manifestation. Shaykh Ahmad, on the other hand, held that all of God's attributes related to creation, even though they be eternal, are created and not in God's Essence.

Interestingly, Mír Dámád (d. 1631/32), the teacher of Mullá Sadrá, also proposed a theory of atemporal, or eternal, creation (hudúth dahrí) as a necessary link between temporal things and God's absolute preeternity. The views of Mír Dámád are very important to this discussion, but need further study before they can be elaborated and before determining how closely they correlate to the thought of Shaykh Ahmad on this issue. In short, Mír Dámád 
divided reality into three distinct ontological realms, instead of the usual two (eternity and creation) of earlier philosophers. The first is the level of the Divine Essence, the dimension of absolute eternity and timelessness (sarmad), wherein no other being exists except God. The second is the level of metatime (dahr), which is also eternal but at the same time created. This is the dimension of permanent immaterial entities, such as the First Intellect. The third is the level of time (zamán), the dimension of temporal, changeable beings. Each of these dimensions has a relation of causation to the dimension below it, so that $d a h r$ is the effect of sarmad, and zamán is the effect of dahr. From another standpoint, the relation of God to the permanent realities is called sarmad; the relation of permanent realities to changeable things is called dahr; and the relation of one changeable thing to another is called zamán. Inasmuch as the physical world is brought into existence through the intermediate dimension of dahr, its creation as a whole is atemporal (dahrî), not temporal (zamání) (Mír Dámád 9-12).

Fazlur Rahman, in commenting on Dámád's view of the essences (máhíyyát) of things, says that although only God's being exists at the level of sarmad, these essences are "with" God at this level "just as our thoughts are with us, having no real separate existence of their own." They are, however, essentially or logically created (hudúth dhátí) because they depend upon God, and not God upon them. They are not created as actualized existents, though, because "there is no real, existential rupture between them and between God's being" (Rahman, "Mír Dámád's Concept" 144-45). Unactualized essences have merely a possible (mumkin) existence, so their "creation" simply means their dependence upon the mind which thinks them, whereas the creation of real concrete beings implies a complete rupture with the being of God. According to Mír Dámád, since nothing actual can coexist with God at the level of sarmad, the process of bringing something into actual existence takes place first atemporally in the dimension of dahr.

'Abdu'l-Bahá's Commentary on "I was a Hidden Treasure ..."

'Abdu'l-Bahá's position on this question, namely, the nature of the relation between the essences of things and God, is essentially a continuation of the position of Shaykh Ahmad. In a commentary in Persian on the famed tradition "I was a Hidden Treasure ..." reportedly written in Baghdad while he was still a teenager, 'Abdu'l-Bahá tactfully argues for the position that God's "ideas" of things by which $\mathrm{He}$ creates them, and which are identical to the realities of the things, are created. His later writings show that he maintained this position until the end of his life. This commentary was addressed to 'Alí Shawkat Páshá, who was probably a Sufi and an admirer of the works of Ibn 'Arabí.

The text of the tradition upon which 'Abdu'l-Bahá is commenting is: "I was a Hidden Treasure and loved to be known. Therefore, I created the creation that I 
might be known."3 'Abdu'l-Bahá divides his elucidation of this tradition into four parts, which correspond to three separate ontological realms. These are (1) the Hidden Treasure, which corresponds to the ontological station of absolute oneness (ahadiyya); (2) the stages of love, which correspond to relationships between each of the ontological levels; (3) timeless creation, which corresponds to the ontological station of unity (wáhidíyya), in other words, the station of unity-multiplicity, in which the essences of things, and the created divine names and attributes, exist distinctly from each other as parts of a unified whole; and (4) creation in time, in which the evolution of particular beings takes place with the ultimate goal of producing perfected human beings capable of knowing their Creator in the fullness of the divine names. In the Bahá'í writings, these three ontological levels are customarily referred to as God, Command (or Primal Will), and creation.

'Abdu'l-Bahá explains that all thinkers on this subject agree in regard to the first ontological level, which is called the station of the True One (haqq), the Absolute Essence (dhát-i-baht), the Hidden Treasure (kanzal-makhfi), the sheer Unknowable One (majhúl al-muțlaq), and other names which refer to the Essence of God. In this station, whatever names and attributes are used to refer to the Essence of God, or whatever essences are said to "subsist" there, only point to the eternal states (shu'únát) of the Essence itself without a trace of distinction from it either conceptually or actually. This is equivalent to saying that the essences of things do not exist at this level in any form whatsoever, because God's oneness and uncompounded nature is absolute and real. 'Abdu'lBahá says:

Know that according to Sufi convention it is affirmed that all names are remote from the court of the sanctity of the Hidden Being in the station of absolute oneness [ahadiyya], and $\mathrm{He}$ is known without name or attribute. For the names of the True One are mirrors of His attributes, and the attributes of the True One in the station of absolute oneness are the same as His Essence without any trace of difference or distinction. As his holiness, 'Alí ibn Abi Tálib, has stated: "Perfect belief in the divine unity consists in the negation of all His attributes." Indeed, the permanent and essential names and attributes can in no way be separated from the Essence of the True One, but rather, in that station, names and attributes are inseparable from each other, nor are they distinguishable from the causeless Essence. The realities of the divine states [shu'únát] cannot be differentiated either conceptually or actually from each other or from the undifferentiated Essence. (Makátíb 2:6; Momen, "AAbdu'1Bahá's Commentary" 8-9) ${ }^{4}$

3. This kind of tradition is known as hadíth-i-qudsí, a holy tradition attributed to Muhammad, in which God Himself speaks.

4. I would like to acknowledge the debt I owe to Moojan Momen for his excellent translation of this commentary of 'Abdu'l-Bahá, a translation which I have revised occasionally in this article for the sake of greater clarity. 
In an even stronger statement, 'Abdu'l-Bahá says: "The names and attributes of God and the essential states are completely and utterly annihilated in the station of absolute oneness so that not a whiff can be inhaled from them of either actual or conceptual existence" (Makátíb 2:8; Momen, “Abdu'l-Bahá's Commentary" 10). As "Abdu'l-Bahá explains, the essences of things come into conceptual existence in the next ontological station, that of the divine knowledge, through the movement (haraka) generated by God's love:

Inasmuch as the movement of love and essential yearning in the Hidden Being necessitated perfect burnishing and clarification - and "perfect burnishing" in the opinion of some mystics is the manifestation of the True One to Himself in the forms of the archetypes, 5 and "clarification" is the gazing of the Absolute Beauty upon the effulgences of His own beauty in the mirrors of realities and archetypes-the essential states became manifested through the most holy outpouring from the station of the Essence into the station of the divine knowledge. . . . From this manifestation the fixed archetypes came into conceptual existence, and each one, according to its inherent nature, became distinguished from the others in the mirror of the divine knowledge. ... And this stage is expressed as the secondary unknown, unity [wáhidíyya], ${ }^{6}$ and the station of the fixed archetypes. These fixed archetypes are the forms of the divine knowledge which have not yet inhaled the fragrance of actual existence. (Makátíb 2:9-10; Momen, “AAbdu'l-Bahá's Commentary” 11-12)

This theory of God's states ( $\underline{s h} u$ 'únát), which give rise to distinct attributes and realities at the next ontological level, is reminiscent of the $\mathrm{Mu}$ 'tazilite theory of states (ahwál) developed by Abú Háshim (d. 933). In the sentence "Zayd is riding," the word "riding" expresses the state of the subject of the act while the act is taking place. In the same way, when we say "God is knowing," the word "knowing" expresses a state of God's Essence distinct from the Essence. "Just as we cannot say that 'riding' is existent or nonexistent apart from Zayd, so we cannot say 'knowing' is existent or nonexistent apart from God" (Watt 300). The Essence remains absolutely one but is described according to the relation of God's action to what is being acted upon. The actions, to which we apply the divine names, "are derived from the attributes which are the perfections belonging to the reality of the Essence" ('Abdu'lBahá, Makátíb 1:49).

The main debate is whether this second ontological station, that of unitymultiplicity (wáhidíyya) or the divine knowledge in which the essences have conceptual existence, is created (hádith) or preexistent/not created (qadím). In the opinion of the followers of Ibn 'Arabí and Mullá Șadrá it is not created,

\footnotetext{
5. "Archetype," being used here to render the word 'ayn (pl., a 'yán), is the equivalent of "species essence" and Platonic Form. 'Ayn was used in this sense by Mullá Sadrá and the philosophers who followed him. In the writings of Ibn "Arabí, however, 'ayn means not "archetype" but an "individual entity."

6. Wáhidíyya means unity in the sense of a whole of unified parts, not in the sense of oneness.
} 
whereas such thinkers as Mír Dámád and Shaykh Ahmad took the position that it is created, though atemporal. It is evident both from 'Abdu'l-Bahá's commentary itself and from his other writings that he also holds the view that the station of the divine knowledge in which the essences of things exist conceptually is created and distinct from the Essence of God, even though it is eternally "with" God. In the commentary on the Hidden Treasure, 'Abdu'1Bahá is addressing a Sufi, or at least a Sufi admirer, so he tactfully expresses his views. But the position he favors is clear by the words with which he describes those who take the viewpoint of creation and by the care with which he treats their arguments. For example, this is how 'Abdu'l-Bahá describes those who take the position that essences are created:

But some of those who know the hidden secrets and are acquainted with the concealed divine mysteries, who have freed their gaze from the limitations of the similes and metaphors of the worlds of plurality, and who with divinely-kindled fire have burned away the luminous veils, and with sharp sight and penetrating vision have witnessed the stations of unity-these consider all archetypes [a'yán], essences [máhíyyát], realities [haqá'iq], and potentialities [qábilíyyát] to be far removed from the shore of the sanctity of the divine knowledge which is identical to the True One. (Makátíb 2:11-12; Momen, “'Abdu'l-Bahá's Commentary” 13)

As for those who call the essences of things uncreated and indistinguishable from the Essence of God, he generally calls them mystics ('árifin) but without any further praise. He says, for example:

However, some of the mystics do not recognize these archetypes, potentialities, realities, and essences as being created and fashioned for several reasons. Firstly, they say that created and fashioned things are originated, and originated things are those that do not exist at one point in time and then come into being. But these realities and archetypes have always been in existence in the mirror of the knowledge of the Lord of Might, for knowledge without an object of knowledge is not possible. Since knowledge is one of the essential attributes, which are the same as the Essence [of God], and is preexistent, therefore if we were to say that these realities and potentialities are created, then we would be asserting-God forbid!-ignorance in the Essence of the Necessary Being. (Makátíb 2:24-25; Momen, “Abdu'l-Bahá's Commentary" 21)

In giving counterarguments from the standpoint of the upholders of the creation of the essences, once again 'Abdu'l-Bahá praises them highly:

But some of those who are informed of the hidden signs and have ascended to the heights of oneness hold that the realities and potentialities are created and formed, and that the archetypes and essences are originated and caused. . . In the paradise of divine unity upon the branches of detachment and twigs of singleness, they have sung this heavenly song and this angelic melody unraveling the difficulties and removing the obstacles mentioned above with regard to the connection of knowledge to objects 
of knowledge. They have clung to firm proofs and convincing arguments to demonstrate that God's knowledge does not require nor depend on objects of knowledge. (Makátíb 2:26-27; Momen, “AAbdu'l-Bahá's Commentary” 22)

'Abdu'l-Bahá then recounts four arguments for the independence of God's Essence from the objects of knowledge, or the essences. The first proof begins by reasserting that the essential attributes are identical to God's Essence without any distinction whatsoever between them and the Essence, and since God's Essence is unknowable, human beings cannot determine whether or not God's essential knowledge stands in need of objects of knowledge or not.

Since it has been established that knowing the Essence of the True One is impossible, then knowing the knowledge which is the same as the Essence of the True One is also impossible, since no difference whatsoever exists between the Essence and the attributes. Consequently, no one can apprehend that knowledge which is identical to the Essence in order to determine whether the relationship between the knowledge of the True One and things requires objects of knowledge or not, or whether it is subsequent to the realities and potentialities of things or not. Certainly, knowledge without an object of knowledge is not possible in the contingent world, but no one knows how the matter stands with respect to the Essence. (Makátíb 2:30; Momen, “'Abdu'l-Bahá's Commentary” 24)

The second and third proofs are similar to each other. In the second one, 'Abdu'l-Bahá says: "If the knowledge of the True One required and called for objects of knowledge and necessitated the potentialities of things, His Essence would also require this, which is false because exigencies and requisites imply need, whereas need is an attribute of possible being and not of the Necessary Being, the True One" (Makátíb 2:32-33; Momen, “Abdu'l-Bahá's Commentary" 25). In the third proof, 'Abdu'l-Bahá states:

They have said that the knowledge of possible being is necessarily dependent on objects of knowledge and is impossible without them. And if the knowledge of the Necessary Being were also dependent on objects of knowledge, it would be the knowledge of possible being. But it is clear and evident that what belongs to possible being cannot be part of the True One, for no similarity, likeness, comparison, or resemblance exists between the Creator and the creature. (Makátíb 2:33; Momen, "“Abdu'l-Bahá's Commentary” 25).

The fourth proof related by 'Abdu'l-Bahá states that "if the archetypes and potentialities of things exist within the Essence of the True One, they must be identical to the Essence of the True One, and therefore they could not be potentialities or realities" for "in what manner then can they be seeking existence when the Essence of the True One exists and has no need of a separate existence." Also if they are objects of knowledge, then they are no 
more than the knowledge the Essence has of its own identity (Makátíb 2:34, Momen, “'Abdu'l-Bahá's Commentary” 26).

In view of these proofs, the supporters of the creation of the essences, concludes 'Abdu'l-Bahá, recognize two kinds of divine knowledge:

In brief, they held two perspectives concerning knowledge. The first is with respect to the reality and identity [of the Essence]; the second is with respect to its state of action. Therefore, in mentioning knowledge, the intention might be (1) that knowledge which is identical to the Essence of the True One, or (2) that knowledge which is dependent on and pertains to objects of knowledge. The first is preexistent and identical to the Essence of the True One; the second is created and identical to [the realities of] created things. (Makátíb 2:35; Momen, "'Abdu'l-Bahá's Commentary" 26)

\section{The Meaning of the Doctrine of the Unity of Existence}

As we will see from a perusal of 'Abdu'l-Bahá's other writings and talks on the subject of the unity of existence, he also upholds the position of created essences and maintains a clear distinction between the existence belonging to God and the existence predicated of created things. 'Abdu'l-Bahá's criticism of Mullá Șadrá and certain Sufis appears to be mainly directed against their theory that the essences and realities of things are uncreated and identical to the Essence of God in the loci of manifestation. In other words, that ontological station which 'Abdu'l-Bahá and Shaykh Ahmad say is distinct from the Essence of God-the domain of unity-multiplicity (wáhidíyya) and the fixed archetypes (a'yán thábita)—Ibn 'Arabí and Mullá Șadrá say is a manifestation (zuuhúr) of the Essence, and so not separate from it substantially. 'Abdu'l-Bahá says this station, instead, is an emanation (sudúr) from the Essence, which means that the two levels cannot be one in substance or existence.

The two other central figures of the Bahá'í Faith, the Báb and Bahá'u'lláh, have also made statements in their writings that support the view that the essences of things are created and distinct from the Essence of God. The Báb, for example, made this observation:

The majority of the philosophers ... have erred in their explanation of this station. They have confused the effulgences [tajallíyat] of the creative act with the Essence of God, and consequently they have adhered to the false proposition requiring the fixed archetypes to be in the Essence in order to establish His knowledge. . . . In truth, the Essence is not connected with anything, for the cause of contingent things is His very creating [san'], which is the Will [mashiyyat] that God created by and through itself without a fire touching it from the Essence. God created the existents through this Will, and it has ever indicated its own self and pointed to its own being. There is no sign which points to God's Essence in the contingent realm, for His Being bars His creatures from knowing Him, and His Essence prevents His servants from understanding Him. (Qtd. in Ra'fati 141) 
Bahá'u'lláh also recounts this theme in a letter to Salmán, and mentions one of its difficulties:

In brief, they [the followers of Ibn 'Arabí] consider all things to be expressions of the self-manifestation [tajallíy-i-dhátí] of God, and for this self-manifestation they have described three stations: (1) that of the Essence, (2) that of the attributes, and (3) that of action. They believe that the subsistence of things by God is a subsistence by manifestation. ... In regard to the existence of the fixed archetypes in the Divine Essence, they have said, as one of the mystic philosophers has written, "The realities of things exist in His Essence, lauded be He, in the noblest state, then He causes them to issue forth," for they do not believe that what gives something can itself lack that thing, and they say this is impossible. Ibn "Arabí has written a detailed exposition on this theme, and the mystic philosophers, and later writers like Mullá Sadrá and Mullá Muhsin Fayḍ have tread in the narrow rivulet of Ibn 'Arabí. . . . (Majmú 'iy-iAlwáh 140-41)

In another important Tablet on this subject known as Lawh Basít al-Haqíqa (Tablet on the Uncompounded Reality), Bahá'u'lláh gives what he considers to be an appropriate or "praiseworthy" (mahmúdih) interpretation of the concept of the unity of existence (tawhíd-i-wujúdî). He explains that this concept should mean that

all things, when compared with His manifestation and remembrance, have been and will continue to be absolute nothingness. . . . As it has been said: "God was and there was nothing else beside Him. He now is as He has always been." And yet it can be seen that things exist and have existed. The meaning of these words is that, in His court, nothing has, or has ever had, existence. In the station of the unity of existence all things perish and are as nothing, while the divine Face, which is the Absolute Reality, is eternal and unceasing. (Má'idiy-i-Ásmání 7:141-42; Momen, "Bahá'u'lláh's Tablet" 9-10) 7

Bahá'u'lláh goes on to say that since "God ... is unknowable, unattainable, and invisible," the real meaning of attaining knowledge of God and "union" with Him is to recognize the Manifestation of God in each age and conform all one's words and actions to His standard. This is the ultimate end of the mystic's quest. For a mystic to claim the station of a Prophet or higher is blasphemy, and to fail to recognize the Manifestation of God is to turn away from God Himself. As for the unity of vision (tawhíd-i-shuhúdí), Bahá'u'lláh says this is witnessing the divine attributes and the reflection of God's uniqueness in all things (Má'idiy-i-Ásmání 7:142; Momen, "Bahá'u'lláh's Tablet" 10).

In one of his table talks with Laura Clifford Barney, 'Abdu'l-Bahá explains that those Sufis who followed Ibn 'Arabí's concept of the unity of existence took the position that archetypes are uncreated because they identified the

7. Translation slightly revised. 
perceiver with the perceptual forms in the divine knowledge (the speech with the speaker, and so on). 'Abdu'l-Bahá emphasizes that although the perceptual form can never exist apart from the perceiver (just as speech cannot exist apart from a speaker), these two are not the same in substance. He also explains that the leaders of the Sufis never intended "unity of existence" to include the realm of physical things, which 'Abdu'l-Bahá calls "this universally predicated existence" (wujúd-i- 'ámm-i-mașdarî), though, he says, many of their uninitiated followers (the Sufi masses) held this view:

[T]he mass of the Súfís believe that the signification of [existence is this universally predicated existence, which is an intelligible and mental construct of man]-that is to say, man comprehends it. Instead of that, this general existence is [an accident inhering in the realities] of beings, [while the essences of beings are the substance]. This accidental existence, which is dependent on [the realities of] beings, is like other properties of things which depend on them. It is an accident among accidents, and certainly that which is the [substance] is superior to that which is the accident. For the [substance] is the origin, and the accident is the consequence; the [substance] is dependent on itself, and the accident is dependent on something else - that is to say, it needs [a substance by which it subsists]. In this case, God would be the consequence of [His creation]. He would have need of it, and it would be independent of Him. (Mufávadát 203-4; Some Answered Questions 292-93) 8

In other words, according to 'Abdu'l-Bahá, there is a qualitative and substantial difference between the existence of God and the existence of created things. What we call "things" are expressions of God's creative Will, which is itself an emanation and not a manifestation of God. Though "things" have both an inner, immaterial reality (bátin) at the level of the Primal Will as well as an outer, material expression (záhir) in the domain of time, they do not subsist through themselves, unlike the existence of God, which is self-subsistent. When 'Abdu'lBahá states above that "the substance is dependent on itself," this clearly refers to its relation to material things, not its relation to God, since all things other than God exist through Him. Furthermore, 'Abdu'l-Bahá explains that the reality we project upon this domain of material, temporal existence is a construct of the mind (mafhúm-i-dhihní). "Materiality" is the product of impressions on minds resulting from the combination of attributes, properties, and symmetries deriving from a level more fundamental than "material" things themselves. To this material existence we predicate the attribute of existence. "Abdu'l-Bahá concludes that if the existence of God were the same as this mentally constructed existence, then God Himself would be a consequence of His creatures and stand in need of them.

8. In this and the following quotations from Some Answered Questions, some changes in Laura Clifford Barney's translation deemed important to better understand 'Abdu'l-Bahá's arguments are inserted in brackets. 
What the leaders of the Sufis intended by "unity of existence," 'Abdu'l-Bahá explains, is not this general, mentally constructed existence. Rather, they meant that the real existence through which all things exist is one; in other words, God is that Unity (wáhid) ${ }^{9}$ and real existence through which all other things come into being. 'Abdu'l-Bahá says: "[W]ith regard to this theory that all things exist by the Unity, all are agreed - that is to say, the philosophers and the Prophets" (Mufávadát 204; Some Answered Questions 293).

For this reason, it is perhaps best not to translate wahdat al-wujúd as "pantheism," at least not with respect to the meaning of the leaders of the Sufis who followed Ibn 'Arabí. But even so, their identity of the realities of things with God's Essence in the state of manifestation is a form of pantheism because it implies that God is, in some sense, also the intelligible things He originates through His Will. If we accept the dictionary definition that "pantheism" is "a doctrine that equates God with the forces and laws of the universe" then the position of the Sufi savants is also a form of pantheism if the transcendent realities of things are equated with the laws of the universe.

'Abdu'l-Bahá gives two arguments, the first similar to what he relates above in his commentary on the tradition of the Hidden Treasure, as to why the realities and essences of things cannot be manifestations of God's Essence, this time associating this view with the Prophets. The first argument is based on the principle that it is improper to make a comparison between God's knowledge and human knowledge due to the complete difference between what is essentially preexistent and what is created.

The Prophets say, The Knowledge of God has no need of the existence of beings, but the knowledge of the creature needs the existence of [objects of knowledge]; if the Knowledge of God had need of any other thing, then it would be the knowledge of the creature, and not that of God. For the Preexistent is different from the [created], and the [created] is opposed to the Preexistent. That which we attribute to the creature — that is, the [necessary concomitants of creation] —we deny for God. . . . The [created] knowledge has need of [objects of knowledge]; the Preexistent Knowledge is independent of their existence. So the preexistence of the specification and of the individualization of beings which are the things known of God the Most High does not exist; and these divine and perfect attributes are not so understood by the intelligence that we can decide if the Divine Knowledge has need of [objects of knowledge] or not. ('Abdu'l-Bahá, Mufávadát 204-5; Some Answered Questions 293-94)

The second argument against the essences of things being manifestations of the Divine Essence is that "manifestation" means the same thing appearing in a different form, like the sea taking on the form of the waves, or the ink the form

9. In the sense of "not multiple." 
of the letters (common Sufi analogies for the unity of existence between God and the perceptual forms in the divine knowledge). But 'Abdu'l-Bahá says this would require dependence and differentiation in the Essence of God:

The difference resides in that which the Súfís say: "The realit[ies] of things [are] the manifestation[s] of the Real Unity [wáhid-i-ḥaqiqí]." But the Prophets say: "[They] emanate from the Real Unity," and great is the difference between manifestation and emanation. Appearance [by] manifestation means that a single thing appears in infinite forms. For example, the seed, which is a single thing possessing the vegetative perfections, which it manifests in infinite forms, [becomes resolved] into branches, leaves, flowers, and fruits. . . . Whereas in appearance through emanation this Real Unity remains and continues in the exaltation of Its sanctity. The existence of creatures is [obtained from it by emanation, not manifestation. The Real Unity] can be compared to the sun. [The rays of the sun emanate from it and shine upon all created things,] but the sun remains in the exaltation of its sanctity. It does not descend, and it does not resolve itself into luminous forms; it does not appear in the substance of things through the specification and the individualization of things; the Preexistent does not become the [created]; independent wealth does not become enchained poverty; pure perfection does not become absolute imperfection. (Mufávadát 205; Some Answered Questions 294-95)

'Abdu'l-Bahá's answer to those Sufis and philosophers who proposed the unity of God's Essence with the realities of things was the same as Shaykh Ahmad's: the realities of things exist in an intermediate level of being between God and creation, which is itself created but shares temporal (though not essential) preexistence with God. Shaykh Ahmad called it God's created knowledge (al-'ilm al-makhlúq) of the possible, which is identical to the realities of things, the Possible and Generative Will, and other names. 'Abdu'lBahá generally refers to this atemporal created reality as the Primal Will (mashíyya awwalíyya), the world of Command ('álam al-amr), the universal reality (haqiqa kullíyya), or the like. It is able to bring the two extremes, God and creation, into relation with each other because it is both eternal and created.

In sum the generality of the mystics imagine that existence is limited to two conditions: God and creation. They believe God to be the inner reality of all things and creation to be the outward appearance thereof. The people of Truth, however, recognize three realms of existence: God, Command (which is the Primal Will), and creation. The Primal Will, which is the realm of Command, is the inner reality of all things, and all beings are therefore the manifestations of the Divine Will, not the manifestations of the Divine Essence and Reality itself. "His are the realms of Command and creation."

As to the station of the Godhead, it is exalted above and sanctified beyond the understanding of all created things, how much more above resolving itself into their realities! His Holiness the Báb (may my life be a sacrifice unto Him) hath stated that the meaning of the verse "The sea hath ever been the sea, and all contingent things its waves and forms" is fulfilled in the Primal Will, not in the Divine Essence. . . . 
In brief, the preeminent Sufis mean by "existence" that through which all things are realized, and which is one, unknown in its attributes, unseen, inaccessible, and severed from all human understanding. But even then, they believe in two stations: God and creation; and they further claim that God Himself hath two stations: that of sanctity and transcendence [tanzíh] ("Nothing is like unto Him"), and that of similarity and resemblance [tashbíh] ("He is the Hearing, the Knowing"). . . .

... Rather [in our view] is it the Primal Will, which consisteth of the radiance and bounties of that Sun [of Reality], that causeth the manifestation, appearance, and visibility of all beings. ('Abdu'l-Bahá, Min Makátíb 1:275-77)

For this reason, wherever 'Abdu'l-Bahá says that God is the composer of things, for example, "it is God who makes the composition" (Some Answered Questions 182), this must be understood metaphorically, because God does not create anything in the temporal domain directly. Rather He creates the essences of things outside of time, and the essences of things, which are equivalent to natural laws, are the direct causes of the composition of things in time when they first appear in the world. In another text, 'Abdu'l-Bahá clearly refers to the atemporal nature of the Primal Will, which encompasses "the possible" before its sequential actualization as real existents in time:

The first thing which emanated from God is that universal reality, which the ancient philosophers termed the "First Mind," and which the people of Bahá call the "[Primal] Will." This emanation, [with respect to] its action in the world of God, is not limited by time or place; it is without beginning or end-beginning and end in relation to God are one. The preexistence of God is [both an essential and a temporal preexistence], and [His creation of the possible (mumkin) is an essential creation (hudúth dhátí), but not a temporal creation]. . . .

Though the First Mind is without beginning, it does not become a sharer in the preexistence of God, for the existence of the universal reality in relation to the existence of God is nothingness.... (Mufávadát 144-45; Some Answered Questions 203)

"Essential creation," according to Avicenna, simply means that something has its existence from another and not due to itself (Goichon 62), so the Primal Will receives its existence from God but it is not preceded by nonexistence in time, which is a condition of temporal creation. All other things, therefore, are created essentially in and by the Primal Will before their actual creation in time. 'Abdu'l-Bahá is saying there are two kinds of eternity, or preexistence. The first is essential and equivalent to God's own being, to which nothing is comparable; the second is dependent upon God but precedes time as its essential precondition. At most, it can be said to be created "with time" but not "in time." The essences or species of things, in the Platonic sense, are created in the second kind of eternal dimension.

In one of the chapters on cosmology in Some Answered Questions, 'Abdu'lBahá explains that the physical domain as a whole is also eternal, just as is the 
inner dimension of creation. At most, "one of the parts of the universe, one of the globes, for example, may come into existence, or may be disintegrated, but the other endless globes are still existing" (180). ${ }^{10}$

\section{A Note on "Metaphysical Relativism"}

In his article "Relativism: A Basis for Bahá'í Metaphysics," Moojan Momen, based upon his reading of 'Abdu'l-Bahá's commentary on the Islamic tradition "I was a Hidden Treasure ...," argues that

'Abdu'l-Bahá appears to be stating that a situation of what might be called metaphysical relativism applies with regard to the Bahá'í view of ontology. . . . 'Abdu'l-Bahá then states that, in his opinion, the proofs and evidences given for both of these positions [created vs. uncreated essences] are equally correct. . . The difference in the viewpoints arise from differences in the fundamental natures (i.e., the attributes predominant within the soul/psyche complex) of the observers. The fundamental nature of one individual inclines him to see Reality in a dualist mode, while another will see Reality in a monist mode. ("Relativism" 201-2)

This statement of 'Abdu'l-Bahá, however, appears to concern epistemology rather than ontology: it is about the limitations of individual understanding of the reality of things rather than about the reality of the things themselves. What 'Abdu'l-Bahá actually says in the commentary is this: "Each viewpoint, relative to the station [or understanding] of the person holding it, is perfect and complete" (Makátíb 2:40). This is not the same as saying that both positions, especially when taken as mutually exclusive contrary propositions, are equally correct. What 'Abdu'l-Bahá appears to indicate in this passage is that given each arguer's specific set of premises, which are limited by the individual's own capacity for understanding, their arguments are valid. As individuals grow in knowledge and experience, however, their perception or understanding of reality changes. Consequently, their understanding is relative, but not the object being viewed. Put another way, the reality of the laws that govern the universe is not relative, but our understanding and formulation of those laws is relative and subject to change as we learn more about the universe in which we live. As we reach higher levels of understanding we gain a wider and more comprehensive viewpoint or perspective, from which the complex

10. What 'Abdu'l-Bahá means by "globe" (kura) in this passage is not clear. In one of his letters, 'Abdu'l-Bahá says: "Just as particulars are infinite in number, so also the vast universal existents and the great realities of the universe are beyond enumeration or computation. . . Consider the following well-known tradition and examine its meanings alluding to the vastness of the universe and its unimaginably awesome expanse: 'God, exalted be He, fashioned one hundred thousand, thousand lamps and suspended the Throne, the earth, the heavens, and whatsoever is between them, even Heaven and Hell-all these in a single lamp. And only God knows what is in the rest of the lamps."” (Min Makátíb 49-50). A "globe" could be something as vast as a galaxy or greater. 
interrelationships of things become evident, and apparent contradictions resolved.

In like manner, human understanding of God's oneness and relation to creation is relative to the spiritual station of the seeker. Higher spiritual stations confer qualitatively greater knowledge. 'Abdu'l-Bahá says that some mystics, because of the predominance of certain divine names in them, were inclined to see the essences of things as uncreated in the divine Essence (the position of wahdat al-wujúd). Other mystics, in a higher station wherein all the divine names are reflected in their beings, were able to see the essences of things as both created and eternal. Although this second position may be similar to Sirhindí's doctrine of wahdat al-shuhúd, further study of Sirhindí's writings is necessary before this can be determined. Bahá'u'lláh in his Seven Valleys indicates there is also a station wherein "the wayfarer leaveth behind him the stages of the 'oneness of being' and [the 'oneness of vision'] and reacheth a oneness that is sanctified above these two stations" (Seven Valleys 39; Áthár-iQalam-i-A 'lá 3:133).

Bahá'u'lláh discouraged his followers from disputing about metaphysical questions. In the Lawh Basít al-Haqíqa, he says, in regard to the philosophical statement, "The uncompounded reality is all things, but is not any one thing":

In short, this statement of the philosopher ${ }^{11}$ is capable of both praiseworthy and vain interpretations. Some of those who have attained, wishing to protect the Cause of God, have outwardly refuted this statement. But this imprisoned servant does not mention anything but the good. Furthermore, this is not the day for human beings to occupy themselves with understanding such things, for knowledge of this statement and others like it has not been and will not be conducive to making souls independent from all save God. (Má'idiy-i-Ásmání 7:144)

What is more important, Bahá'u'lláh emphasizes in the Lawh Basít al-Ḥaqíqa, is recognizing the Manifestation of God for the Day in which one lives, and then adapting one's life to be in accordance with his teachings. In other words, understanding God's purpose for man is more important than understanding the reality of God's nature, which is impossible to know anyway. ${ }^{12}$

\footnotetext{
11. Although Mullá STadrá made this statement one of the cornerstones of his philosophy, its origins in Arabic may go back to a book known as The Theology of Aristotle, which is really the Enneads of Plotinus but which was erroneously identified by Muslim philosophers as one of the works of Aristotle. As 'Abdu'l-Bahá in Some Answered Questions, chapter 82, attributes this statement to Aristotle, it is likely that "the philosopher" being referred to here is Aristotle and not Mullá Șadrá. In Enneads 5.2.1, we find: "The One is all things but not a single one of them."

12. However, it is clear that Bahá'u'lláh did not regard all viewpoints or interpretations on the subject as equally correct. See, for example, his refutation of monistic interpretations of the relationship of God and creation in Gleanings 187-92.
} 


\section{Concluding Thoughts}

Although humans can never understand the nature of God, the correctness or incorrectness of doctrines such as the unity of existence is not merely an abstract metaphysical issue remote from everyday reality. Fundamental assumptions on the nature of God matter because they have practical implications and consequences. 'Abdu'l-Bahá's response to the Sufi doctrine of the unity of existence was and is an important issue because belief in the doctrine of the unity of existence, even taking into account the difference between the views of the Sufi masses and their renowned leaders, can easily degenerate into full pantheism: the belief that God and His creatures are two sides of the same coin or one in existence, like the sea and its waves. This idea threatens to undermine the essential distinction between God and creation. Not only that, but the doctrine of the unity of existence, as explicated by Ibn 'Arabí's school, has the potential to undermine the authority of revealed religion, since it makes all human beings potentially divine. As explained by Nader Saiedi, those who held this position believed that "Through the spiritual journey [of the mystic] . . . the soul can transcend the realm of diversity and become aware of the unity of being . . . become one with Reality and attain the station of sainthood or vilayah," a station which most Sufis placed "above the station of prophecy and apostolic legislation" (72-73). Whoever attains this station is said to be able to produce miracles (karámat).

A mystic, therefore, who claims to have reached the station of union with God can also claim to know God's will and disregard the laws and prescriptions of the Holy Scriptures. This was not an uncommon occurrence among those who professed to follow the Sufi way. For example, Ahmad al-T ijání (1737-1815) claimed to be the "seal of God's friends," believed himself to be sinless, and guaranteed salvation through faith in him without requiring his followers to observe religious laws. A Khálidí Sufi, Ibráhím Khalíl (1828-1907) believed his supernatural powers to be so strong that it was his own spiritual intervention that gave Japan the victory in the Russo-Japanese war of 1904-5 (Baldick 142, 149). Bahá'u'lláh, in regard to this same tendency to exalt Sufi sainthood above Prophethood, wrote:

That which the aforesaid persons [Sufis] have mentioned concerning the stations of Divine Unity will conduce in no small measure to idleness and vain imaginings. These mortal men have evidently set aside the differences of station and have come to regard themselves as God, while God is immeasurably exalted above all things. Every created being however revealeth His signs which are but emanations from Him and not His Own Self. (Tablets 60)

In his Kitáb-i-Aqdas Bahá'u'lláh prohibited certain popular manifestations of Sufism, such as practicing feats of asceticism, monasticism, mendicancy, indolence, uncleanliness, the use of narcotics, and disregard for religious laws. 
Some examples of discredited "popular" Sufi practices include the following: the practice of attracting "blame" by carrying buckets of excrement around in public, or by carrying out similar humiliating acts for the purpose of suppressing personal vanity; and the practice of eating live coals, snakes, or glass (this was outlawed in Egypt in 1881). The Hungarian orientalist Arminius Vambery, who disguised himself as a dervish in 1863 in Iran, claimed that in Central Asia, Sufi brotherhoods served as an excuse for widespread mendicancy and their members appeared to be lazy and preoccupied with the consumption of opium and cannabis. According to Baldick (chap. 4), the prevailing rejection of marriage by wandering dervishes was also accompanied by a tendency to pederasty.

In sum, 'Abdu'l-Bahá argued against the doctrine of the unity of existence as held by Mullá Sadrá and certain Sufis, insofar as they regarded the essences and potentialities of things as uncreated manifestations of God's Essence. He taught, instead, that there is an essential distinction and duality between God and creation, though the essences and realities of things are created outside of time, and that they emanate from God, as speech emanates from a speaker. They are eternally "with" God, but not "in" God. The realities of things are manifestations of the first thing to emanate from God, the Primal Will, which is identical to the world of Command. But they are not manifestations of the unknowable and inaccessible Godhead.

Though recognizing the arguments for the unity of existence as valid from a certain perspective, 'Abdu'l-Bahá held that the truth of this position is relative to the spiritual station of the wayfarer on the path of mystic knowledge. At a higher stage, wherein all the divine names are reflected in the being of the wayfarer, the position of separate created essences is a more accurate description of reality. ${ }^{13}$

Again and again, the Bahá'í writings emphasize that the true meaning of union (or knowing) in the mystic quest is not union with (or knowing) the Essence of God (which is impossible to attain), but recognition of the Manifestation of God for the day in which one lives. In the conclusion of his commentary on the tradition of the Hidden Treasure, 'Abdu'l-Bahá affirms:

\footnotetext{
13. Shoghi Effendi, in a letter written on his behalf, also confirms the latter position: "In a Tablet Bahá'u'lláh says that even though absolute being can be attributed only to God we cannot say that other objects have no being. A table has an existence even though its existence compared with the existence of the carpenter who is its maker is almost nothing. Compared to God nothing has existence but this does not mean that even stones do not have being. It is speaking relatively. Moreover, God reveals Himself in all things in the sense that $\mathrm{He}$ is the source of their being and the Cause of their existence. Without Him all things will shrink down into nothing. This however does not mean that all things are parts of God as the pantheist believes. The pantheist says that only God exists, objects are mere modes of His attributes. Bahá'u'lláh however says that objects have a separate reality that is created by God" (In Lights of Guidance 480).
} 
As for what is intended by Knowing, know thou $\mathrm{O}$ wayfarer upon the path of guidance that the path to knowing the innermost Essence of the True One is closed to all beings and seeking and hoping for this station is not acceptable. . . Rather the meaning of Knowing in this holy tradition is recognizing the Manifestation of God in the holy dawning-places of the divine oneness, that is to say, in the Prophets and Holy Ones. Other than this the true nature of His Essence has never been nor will ever be knowable to any soul. (Makátíb 2:44, 49-50; Momen, "Abdu'l-Bahá's Commentary" 30, 33)

\section{Works Cited}

'Abdu'l-Bahá. Makátíb-i- 'Abdu’l-Bahá (Collected Letters of 'Abdu'l-Bahá). Vols. 1-2. Cairo, 1910-11. Min Makátíb-i- 'Abdu'l-Bahá (From the Collected Letters of 'Abdu'lBahá). Vol.1. Rio de Janeiro: Editora Bahá'í Brasil, 1982. . Mufávadát (Table Talks). 1920. New Delhi: Bahá’í Publishing Trust, 1984. . Some Answered Questions. Comp. and trans. Laura Clifford Barney. 4th ed. Wilmette, Ill.: Bahá'í Publishing Trust, 1981.

Aḥsá'í, Shaykh Ahmad. Sharh al-Mashá'ir. Tabriz: n.p., 1278 A.H.

Ansari, M. Abdul Haq. "Shah Waliy Allah Attempts to Revise Wahdatu'lWujúd." Islamic Quarterly 28.3 (1984): 150-64.

Bahá'u'lláh. Áthár-i-Qalam-i-A 'lá. Vol. 3. Tehran: Bahá'í Publishing Trust, 121 в.E.

- Gleanings from the Writings of Bahá'u'lláh. Trans. Shoghi Effendi. Wilmette, Ill.: Bahá'í Publishing Trust, 1976.

__ Má'idiy-i-Ásmání (The Heavenly Bread). Comp. 'Abdu'l-Hamíd Ishráq Khávarí. Vol. 7. Tehran: Bahá’í Publishing Trust, 129 B.E.

. The Seven Valleys and the Four Valleys. Trans. Marzieh Gail and AliKuli Khan. Wilmette, Ill.: Bahá'í Publishing Trust, 1973.

- _ Tablets of Bahá'u'lláh Revealed after the Kitáb-i-Aqdas. Comp. Research Dept. of the Universal House of Justice. Trans. H. Taherzadeh et al. 2d ed. Wilmette, Ill.: Bahá'í Publishing Trust, 1988.

Baldick, Julian. Mystical Islam: An Introduction to Sufism. New York: New York University Press, 1989.

Brown, Keven. “'Abdu'l-Bahá's Response to Darwinism: Its Historical and Philosophical Context." Evolution and Bahá'í Belief. Studies in the Bábí and Bahá'í Religions Vol. 12. Los Angeles: Kalimát Press, 2001. 1-134.

Chittick, William C. The Self-Disclosure of God: Principles of Ibn al- 'Arabi's Cosmology. Albany: State University of New York Press, 1997.

-_- The Sufi Path of Knowledge. Ibn al-'Arabi's Metaphysics of Imagination. Albany: State University of New York Press, 1989.

"Wahdat al-Wujúd in Islamic Thought." Bulletin of the Henry Martyn Institute of Islamic Studies Jan.-Mar. 1991: 7-27. 
Dámád, Mír. Al-Qabasát. 2d ed. Tehran: University of Tehran, 1988.

Goichon, A. M. Lexique de la langue philosophique d'Ibn Síná. Paris: Desclée de Brouwer, 1938.

Lights of Guidance: A Bahá'i Reference File. Comp. Helen Hornby. 3d ed. New Delhi: Bahá'í Publishing Trust, 1994.

Momen, Moojan. “'Abdu'l-Bahá's Commentary on the Islamic Tradition: 'I was a Hidden Treasure ..."'Bahá'í Studies Bulletin 3.4 (1985): 4-37.

___ . "Bahá'u'lláh's Tablet of the Uncompounded Reality (Lawh Basít alHaqíqa).” Abhá: A Journal of Bábí-Bahá'í Studies 1.1 (1997): 1-15.

__ _ "Relativism: A Basis for Bahá'í Metaphysics." Studies in Honor of Hasan M. Balyuzi. Studies in the Bábí and Bahá'í Religions Vol. 5. Los Angeles: Kalimat Press, 1988. 185-217.

"Pantheism." Merriam-Webster's Collegiate Dictionary. 10th ed. 1993.

Plotinus. Enneads. In Plotinus, with an English Translation by A. H. Armstrong. Loeb Classical Library. Cambridge: Harvard University Press, 1966-88.

Ra'fati, Vahid. "The Ideas of Ibn 'Arabí in the Bahá'í Writings." Maḥbúb-i'Alam. 'Andalíb Editorial Board, 1992-93. 139-57.

Rahman, Fazlur. "Mir Dámád's Concept of Húduth Dahrí." Journal of Near Eastern Studies 39.2 (1980): 139-51.

- The Philosophy of Mullá Sadrá. Albany: State University of New York Press, 1975.

Ṣadrá, Mullá. Al-Hikmat al-Muta 'álíya fi'l-Asfár al- 'Aqlíya al-Arba 'a (The Sublime Wisdom in Four Journeys of Reason). 9 vols. Qum, 1368-79 A.H.

Saiedi, Nader. Logos and Civilization: Spirit, History, and Order in the Writings of Bahá'u'lláh. Bethesda: University Press of Maryland, 2000.

Watt, Montgomery. The Formative Period of Islamic Thought. Edinburgh: Edinburgh University Press, 1973. 